\title{
Ažuriranje zapisov v VIAF in priporočila za kakovostnejši prikaz slovenskih normativnih zapisov v VIAF
}

\section{Updating records in VIAF and recommendations for higher quality display of Slovenian authority records in VIAF}

\section{Andreja Krajnc Vobovnik ${ }^{1}$}

IZVLEČEK: V prispevku so opisani ažuriranje slovenskih normativnih zapisov v VIAF, vpis identifikatorjev $\checkmark$ bazo podatkov CONOR.SI in njihov prikaz $v$ COBISS+. Pri večini normativnih zapisov je ažuriranje $v$ VIAF potekalo odlično, le pri nekaj zapisih za osebna imena so se pri združevanju $v$ skupke pojavile napake, ki smo jih uvrstili $v$ štiri skupine in jih primerjali s tipičnimi problemi pri vpisu, opisanimi $v$ dokumentu VIAF Guidelines. Na osnovi vpisa zapisov v VIAF in analize napačnih povezav smo oblikovali splošna priporočila za kreiranje normativnih zapisov za osebna imena, da bi bilo pri vpisu in ažuriranju zapisov v VIAF $v$ prihodnosti čim manj napak, ki nastanejo $v$ normativni bazi podatkov CONOR.SI pri katalogizaciji. Opisana so tudi priporočila za ravnanje z normativnimi zapisi, ki so že bili poslani v VIAF. Namen prispevka je tudi ozaveščanje katalogizatorjev o pomenu normativne kontrole na globalnem nivoju in poudarjanje, da njihov intelektualni prispevek pri tem ni zanemarljiv.

KLJUČNE BESEDE: normativni zapisi, osebna imena, imena korporacij, CONOR.SI, VIAF, ISNI, Slovenija

ABSTRACT: The article describes the process of updating Slovenian authority records in VIAF, the entry of identifiers into the CONOR.SI database and their display in COBISS+. For most authority records, the updating in VIAF went smoothly, whereas in some records for personal names errors occurred during the process of putting them into clusters, which were then sorted into four groups and compared with the typical entry-related issues described in the VIAF Guidelines. Based on the entry of records in VIAF and the analysis of erroneous links, we compiled general recommendations for creating authority records for personal names in order to avoid errors in the future, which occur in the CONOR.SI authority database during cataloguing. The aim of this article is also to educate cataloguers on the importance of authority control on a global level and to emphasise that their intellectual contribution is not negligible.

KEYWORDS: authority records, personal names, corporate body names, CONOR.SI authority database, VIAF, ISNI, Slovenia

\section{Uvod}

Eden izmed glavnih konceptov normativne datoteke VIAF je ohranitev nacionalnih ali lokalnih oblik imena v normativnih zapisih, ki so kreirane na osnovi različnih katalogizacijskih pravil. Uporabnik namreč želi prikaz izvornih verzij normativnih zapisov v različnih jezikih, pisavah in črkovanjih. Ista oseba iz različnih virov se v VIAF identificira s primerjavo normativnih točk dostopa ter $z$ variantnimi in sorodnimi točkami dostopa. Ko se imena ujemajo, se primerjajo še dodatni podatki, ki potrdijo ujemanje. Pri osebah so ti podatki letnica rojstva, letnica smrti,

\footnotetext{
${ }^{1}$ Andreja Krajnc Vobovnik, strokovna sodelavka, Institut informacijskih znanosti (IZUM), Maribor, Slovenija, andreja.krajncvobovnik@izum.si.
} 
obdobje delovanja in podatki iz bibliografskih zapisov, predvsem naslovi del (Bennett et al., 2006).

V VIAF se soočajo s težavami pri povezovanju določenih vrst imen v skupke (angl. clusters) zaradi velike raznolikosti oblik imen $v$ različnih jezikih, zato spodbujajo članice VIAF, naj jim sporočijo napake, ki jih nato ročno popravijo. Pri združevanju normativnih zapisov se pogosto srečujejo z naslednjimi tipičnimi problemi (VIAF Guidelines, 2019):

- Pomešana imena (pomešani homonimi): Pojavijo se, ko se naslovi del, ki bi morali biti povezani z različnimi ločenimi entitetami, vsi povežejo samo z eno od teh entitet.

- Manjkajoči naslovi del in datumi: VIAF potrebuje za diferenciacijo med entitetami dovolj podatkov; če so osebna imena brez datumov ali naslovov del, je primerjanje oteženo.

- Neobičajno kodirani podatki: Ustanova pri katalogizaciji uporablja netipična lokalna katalogizacijska pravila.

- Razlikovanje z uporabo jezikovno odvisnih podatkov: Pri osebnih imenih je kvalifikator v podpolju 200c - Dodatki k imenu (ne datumi) (v formatu COMARC/A) oblikovan v jeziku katalogizacije. Pri večini primerjav se ta podatek zaradi jezikovnih različic običajno ne upošteva.

- Podvojeni zapisi: V VIAF se trudijo, da bi vključevali en zapis iste članice VIAF v isti skupek. VIAF občasno objavi sezname potencialnih podvojenih zapisov, ki so uporabni pri razreševanju tako za VIAF kot za sodelujočo ustanovo. Podvojeni zapisi pogosto povzročijo, da se skupek kasneje razcepi.

- Klasična imena, imena kraljev, kraljic in papežev: Zaradi velike raznolikosti oblik imen v različnih jezikih je združevanje zelo zahtevno. V VIAF probleme, na katere opozorijo članice VIAF, rešujejo ročno.

$\checkmark$ prispevku probleme podrobneje opišemo in jih ponazorimo s primeri iz baze podatkov CONOR.SI. Opisani problemi se nanašajo samo na osebna imena, ker smo v VIAF poslali premalo normativnih zapisov za imena korporacij, da bi lahko podrobneje analizirali napake pri združevanju. S sodelavci VIAF (VIAF Team) smo odlično sodelovali; napake, povezane z napačnim združevanjem $v$ skupke, so hitro odpravili. Nekaterih izmed predstavljenih primerov zato ne moremo več najti v VIAF.

V nadaljevanju prispevka želimo katalogizatorjem predstaviti, na kaj naj bodo pozorni pri določanju normativnih točk dostopa in urejanju normativnih zapisov, da bi zagotovili boljšo kakovost tako baze podatkov CONOR.SI kot tudi slovenskih normativnih zapisov v VIAF. V prihodnje bi radi odpravili razloge, zaradi katerih pri združevanju slovenskih normativnih zapisov $v$ skupke nastajajo tipične napake, ki smo jih prepoznali pri preverjanju vključenih zapisov in se ujemajo z nekaterimi tipičnimi problemi, opisanimi v dokumentu VIAF Guidelines.

\section{Ažuriranje zapisov iz baze podatkov CONOR.SI v VIAF}

Skoraj leto dni po inicialnem pošiljanju smo novembra 2019 za VIAF prvič pripravili podatke za ažuriranje. Poleg tega smo tudi prvič poslali normativne zapise za imena korporacij. $V$ izboru je bilo 64.869 normativnih zapisov, od tega jih je bilo 3.523 novih (3.449 za osebna imena in 74 za imena korporacij). V VIAF je bilo tokrat vpisanih 5,05 \% vseh normativnih zapisov iz baze podatkov CONOR.SI, s katerimi je povezanih 2.081.065 pripadajočih bibliografskih zapisov, tj. $38,5 \%$ bibliografskih zapisov iz baze podatkov COBIB.SI. Delež obeh vrst zapisov se je pri prvem 
ažuriranju glede na inicialni vpis le za malenkost povečal. Pri normativnih zapisih se je povečal za $0,05 \%$, pri bibliografskih pa za 0,5\%.

Za ažuriranje zapisov v VIAF pošiljamo trenutno stanje ustreznih normativnih zapisov in pripadajočih bibliografskih zapisov. Izbor zapisov za osebna imena je ostal enak kot pri inicialnem vpisu (Krajnc Vobovnik, 2018). Izbor zapisov za imena korporacij je podoben izboru za osebna imena, razlikuje se $v$ nekaj podrobnostih, ki so vezane na značilnosti normativnih zapisov za imena korporacij. Po pravilu v COMARC/A je normativni zapis dokončno popravljen, ko je v podpolju 001a - Status zapisa vpisana koda "c « - popravljen zapis in je v podpolju 100b - Koda za status normativne točke dostopa koda "a - sprejeta. Za korporacije smo izbor seveda omejili na zapise s kodo "bu - ime korporacije v podpolju 001c - Vrsta entitete. Normativne zapise smo iz formata COMARC/A konvertirali v format MARC 21/A in tako kot pri osebnih imenih izločili podatke, ki niso za javno rabo (830 - Splošna katalogizatorjeva opomba), in podatke v bloku $9 X X$ - Blok za nacionalno rabo, ki niso namenjeni mednarodni izmenjavi. Nato smo za vsak normativni zapis za ime korporacije, ki ustreza zgornjim pogojem, $\checkmark$ bazi podatkov COBIB.SI poiskali pripadajoče bibliografske zapise (po številki normativnega zapisa v podpoljih 71X3). Pri tem smo izločili normativne zapise, ki v bazi podatkov COBIB.SI nimajo nobenega bibliografskega zapisa, zapise za dogodke (izvedena dela), zapise, označene za brisanje, prve vnose zapisa, CIP-zapise in zapise za raritete. $V$ izbor za pošiljanje je prišlo samo 74 zapisov za ime korporacije, kar predstavlja komaj 0,5 \% vseh normativnih zapisov za korporacije, čeprav smo normativno kontrolo korporacij vzpostavili prej, jeseni 2018.

Pred ažuriranjem zapisov, ki so že bili poslali v VIAF, smo v bazi podatkov CONOR.SI preverili, ali še imajo vpisane kodirane podatke, na katerih temelji izbor normativnih zapisov. Ugotovili smo, da se je pri 19 normativnih zapisih pojavila sprememba, zaradi katere se ne bi več uvrstili v izbor. Spremenjeni so bili naslednji podatki: Pri treh zapisih je koda za status normativne točke dostopa (podpolje 100b) spremenjena iz sprejeta (koda »a«) v začasna (koda »c«). Iz zapisov nismo mogli ugotoviti vzroka za to spremembo. Pri 16 zapisih pa je koda za status zapisa (podpolje 001a) spremenjena iz popravljen zapis (koda »c«) nazaj v nov zapis (koda $» n \ll)$.

Omenjenih zapisov pred pošiljanjem nismo ponovno preverjali ali popravljali. Smo pa vse katalogizatorje, ki so v 16 zapisih spremenili status zapisa, opozorili na pomen kod, ki vplivajo na izbor zapisov. Ugotovili smo, da so zapisi, ki so že bili vpisani v VIAF in so pri ažuriranju zaradi spremembe kodiranih podatkov izpadli iz novega izbora, brisani tudi iz VIAF. To želimo pri programskem vpisu v VIAF v prihodnje preprečiti oz. zmanjšati na najmanjšo možno raven, kar je eden izmed namenov tega pisanja. Pred pošiljanjem bomo take zapise preverjali in katalogizatorje zaprosili za dodatno preverjanje normativnih zapisov in za morebitne popravke.

\section{Vpis identifikatorjev $\mathbf{v}$ bazo podatkov CONOR.SI in prikaz v COBISS+}

Pri preverjanju stanja zapisov, ki so na strani VIAF Dataset (http://viaf.org/viaf/data/) mesečno objavljeni za celoten VIAF, smo ugotovili, da so bili tako kot pri inicialnem vpisu tudi pri prvem ažuriranju v VIAF vpisani vsi poslani normativni zapisi. Pri tem so zapisi pridobili identifikator VIAF ID, polovica od teh zapisov pa tudi ISNI (angl. International Standard Name Identifier). Oba smo vpisali v bazo podatkov CONOR.SI: v polje 035 - Kontrolne številke zapisov iz drugih sistemov smo vpisali VIAF ID, v polje 010 - Mednarodni standardni identifikator imen (ISNI) pa 
ISNI. Datum vpisa se programsko vpiše kot zadnji podatek v sistemsko generiranem polju (Conversion) (slika 1).

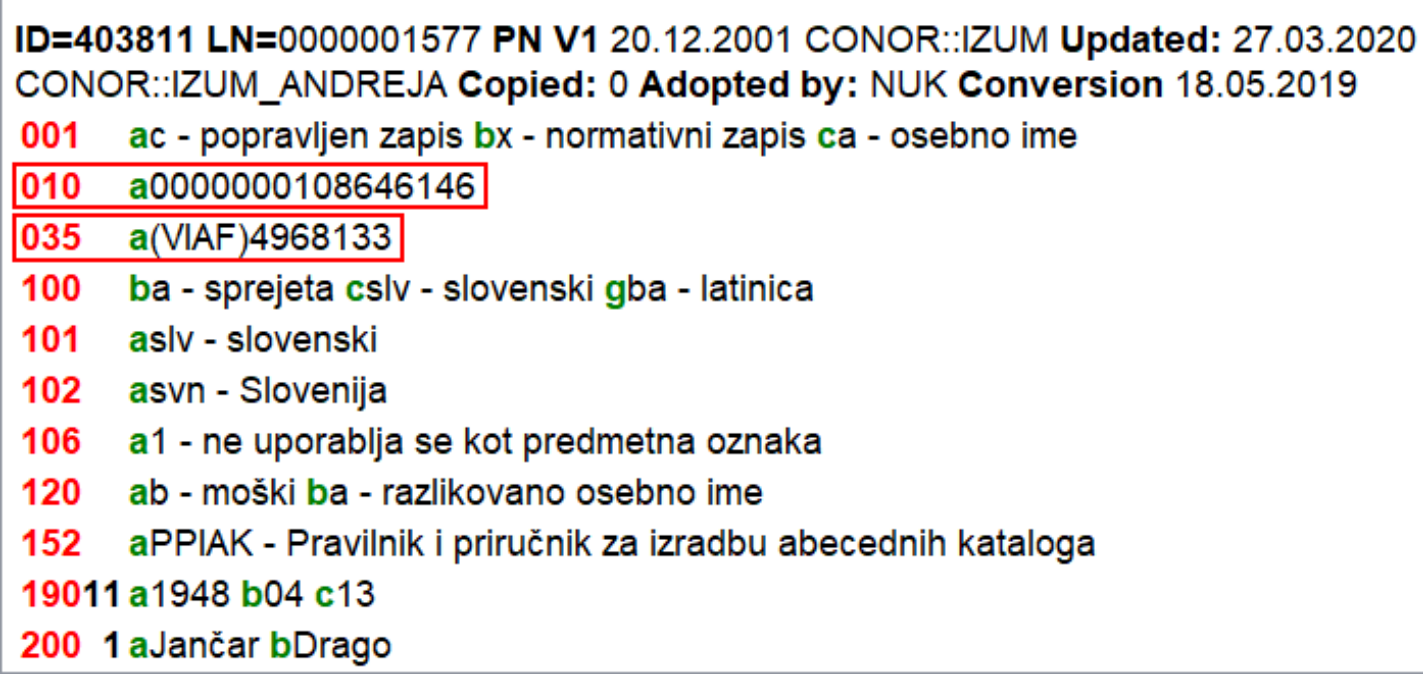

Slika 1: Identifikatorja VIAF ID in ISNI v normativnem zapisu za Draga Jančarja (Vir: CONOR.SI, 2020)

Na osnovi vpisa $v$ normativne zapise smo $v$ javno dostopni bazi podatkov CONOR.SI v COBISS+ omogočili prikaz obeh identifikatorjev in vzpostavili povezavo do servisov VIAF in ISNI (slika 2).

Pri preverjanju vključenih zapisov smo ugotovili, da je identifikator ISNI pri inicialnem vpisu v VIAF pridobilo $48,4 \%$ poslanih normativnih zapisov za osebna imena (29.712 zapisov), po prvem ažuriranju pa že 50,3 \% poslanih zapisov (32.639 zapisov), od tega samo 6 zapisov za ime korporacije ( $8 \%$ poslanih zapisov za ime korporacije), med njimi za dve slovenski ustanovi, in sicer za Nacionalno in univerzitetno knjižnico Ljubljana (ISNI 0000000122863964 ) in Mestni muzej Ljubljana (ISNI 000000011015 6429). Visok delež pridobljenih ISNI za osebna imena je spodbuden, saj je ena izmed poglavitnih prednosti vpisa slovenskih normativnih zapisov v VIAF tudi brezplačna pridobitev ISNI (Krajnc Vobovnik, 2018).

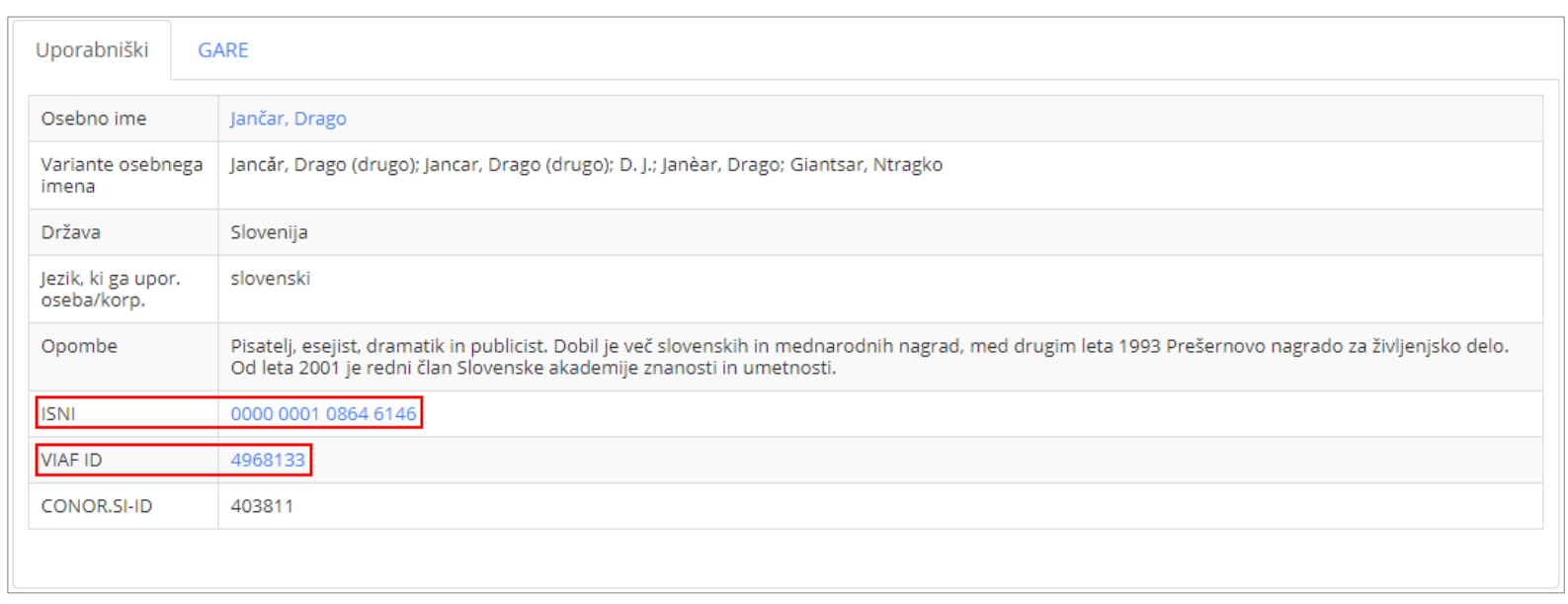

Slika 2: Prikaz identifikatorjev VIAF ID in ISNI v normativnem zapisu za Draga Jančarja (Vir: COBISS+, 2020) 


\section{Problemi pri vpisu normativnih zapisov za osebna imena v VIAF}

Za vse normativne zapise, ki so vpisani v VIAF, smo iz datoteke VIAF Dataset pripravili seznam VIAF ID-jev, ki pripadajo posameznim CONOR.SI-ID-jem.

Na tem seznamu smo preverili, ali obstajajo tudi podvojeni VIAF ID-ji. Analiza je pokazala, da je imelo podvojen VIAF ID samo 11 slovenskih normativnih zapisov. Pri podrobnejšem preverjanju smo ugotovili, da jih lahko razvrstimo v štiri skupine:

1. podvojeni zapisi v bazi podatkov CONOR.SI (4 zapisi),

2. napačne povezave $z$ normativnimi zapisi $v$ bibliografskih zapisih $v$ bazi podatkov COBIB.SI (2 zapisa),

3. razlike $v$ katalogizacijskih pravilih (1 zapis),

4. napačno združeni zapisi v VIAF (4 zapisi).

Normativni zapisi za isto entiteto, ki so jih kreirale različne članice VIAF, se v VIAF združujejo v skupke, kjer je vsaka članica predstavljena z lastnim simbolom, običajno z nacionalno zastavo. Zato se dva zapisa $z$ istim VIAF ID-jem, ki ju je prispevala ista članica, pojavita $v$ istem skupku in ju lahko pri pregledovanju hitro opazimo že na osnovi podvojenega simbola (slika 3).

\subsection{Podvojeni zapisi v bazi podatkov CONOR.SI}

Ena izmed pridobitev vpisa normativnih zapisov v VIAF je tudi seznam potencialnih podvojenih zapisov v bazi podatkov CONOR.SI, ki smo ga dobili iz datoteke VIAF Dataset. Pred pošiljanjem nismo pričakovali, da bomo v VIAF poslali podvojene zapise, saj smo $v$ izbor zajeli samo normativne zapise s sprejeto točko dostopa (100b = »a« - sprejeta normativna točka dostopa) in dokončno popravljene zapise, tj. zapise brez slovničnih in vsebinskih napak $(001 a=» c$ « popravljen zapis), med katerimi ne bi smelo biti podvojenih zapisov. Pri vseh štirih podvojenih zapisih smo ugotovili, da gre za tuje avtorje. Pri treh so avtorji z dvema osebnima imenoma, kjer je $v$ enem normativnem zapisu drugo osebno ime vpisano $v$ izpisani obliki, $v$ drugem pa samo z začetnico. Pri enem podvojenem zapisu pa gre za različen vpis nemške črke.

Primer avtorja z dvema osebnima imenoma je ameriški matematik, fizik, astronom in filozof Charles Sanders Peirce. V bazi podatkov CONOR.SI sta bila dva normativna zapisa: Peirce, Charles Sanders, 1839-1914 (CONOR.SI-ID 52600675), in Peirce, Charles S., 1839-1914 (CONOR.SI-ID 196990819). Oba zapisa sta v VIAF (slika 3) pravilno združena $v$ isti skupek (http://viaf.org/viaf/89203252). V bazi podatkov COBIB.SI je bila številka prvega normativnega zapisa vpisana $\vee 15$ bibliografskih zapisih, številka drugega pa $\vee 7$ bibliografskih zapisih. Avtorjevo ime je $v$ različnih bibliografskih zapisih navedeno $v$ obeh oblikah. Pri preverjanju oblike imena v polju 200 - Naslov in navedba odgovornosti smo ugotovili, da je izpisana oblika imena navedena v 8 bibliografskih zapisih, oblika z začetnico pa v 12 zapisih, v dveh zapisih pa je avtor naveden samo s priimkom. Pri urejanju zapisov smo obdržali zapis z izpisano obliko imena Peirce, Charles Sanders, 1839-1914 (CONOR.SI-ID 52600675). Po slovenskih katalogizacijskih pravilih damo prednost izpisani obliki imena, če avtor uporablja tako začetnice oz. krajšave imena kot izpisano obliko imena (ZNAČKA, 2001). Skrajšana oblika imena je navedena kot variantna oblika v polju 400 - Variantna točka dostopa. 


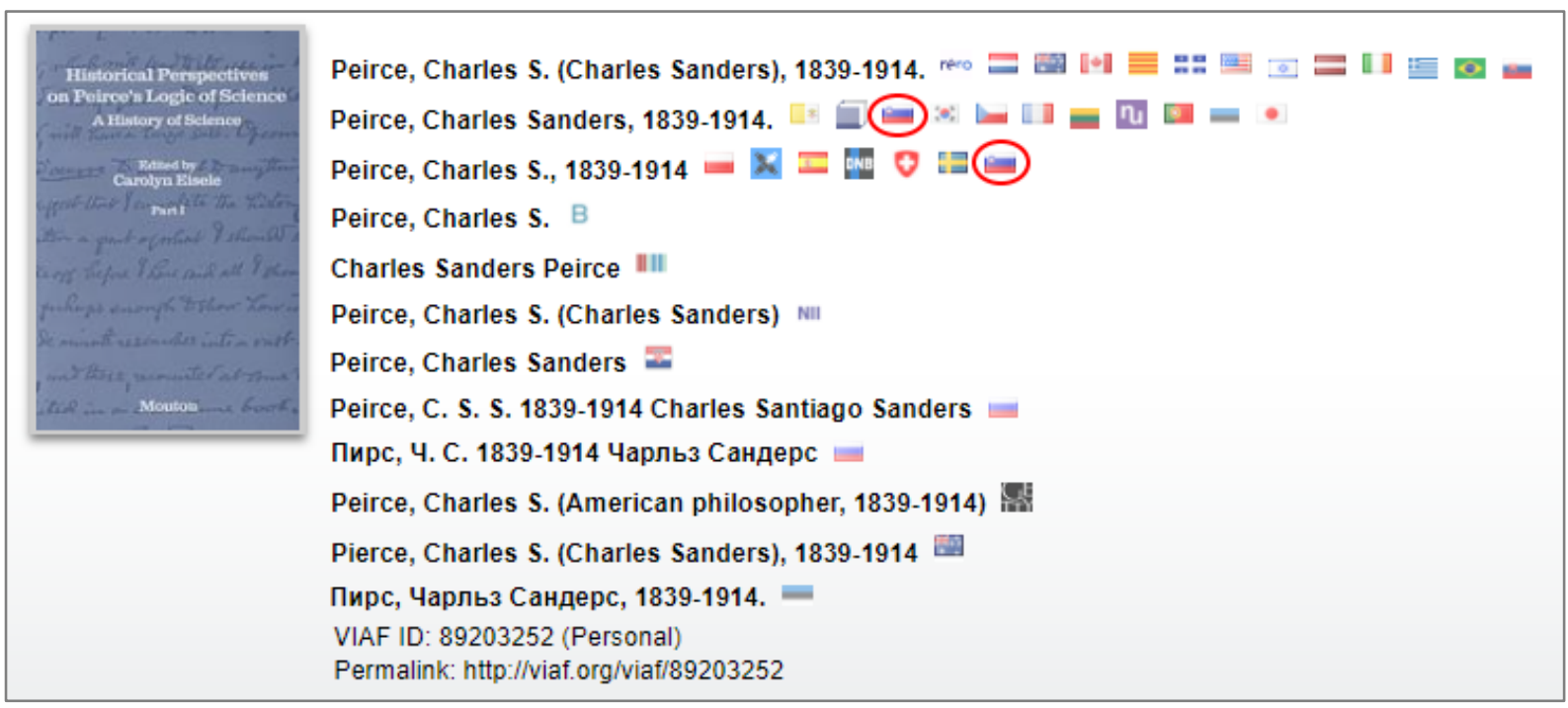

Slika 3: Skupek za osebno ime Charles Sanders Peirce z dvema normativnima zapisoma iz baze podatkov CONOR.SI (Vir: VIAF, 2020)

Pri enem paru podvojenih zapisov smo ugotovili, da gre za različen zapis nemške črke. V enem normativnem zapisu je nemški priimek vpisan z dvojnim $s$ (Kussmaul), $v$ drugem pa z ostrim $s$ (Kußmaul). V bazi podatkov CONOR.SI sta bila dva normativna zapisa: Kußmaul, Paul (CONOR.SI-ID 130775651) in Kussmaul, Paul (CONOR.SI-ID 59414115). Oba zapisa sta v VIAF pravilno združena $v$ isti skupek (http://viaf.org/viaf/44457218). V bazi podatkov COBIB.SI je številka prvega normativnega zapisa vpisana v 3 bibliografskih zapisih, številka drugega pa v 5 bibliografskih zapisih. Pri urejanju podvojenih zapisov smo obdržali zapis za Kußmaul, Paul (CONOR.SI-ID 130775651), ki ima vpisano izvorno obliko priimka. Po slovenskih katalogizacijskih pravilih normativno obliko pišemo $v$ latinici in po potrebi uporabimo tudi neslovenske črke (ć, đ, w, y, ü itn.) oz. upoštevamo tipografijo, ki jo uporablja avtor (ZNAČKA, 2001). Druga oblika imena je navedena kot variantna oblika v polju 400 - Variantna točka dostopa.

\subsection{Napačne povezave osebnih imen $v$ bazi podatkov COBIB.SI}

Predvidevamo, da je napačna povezava pri oblikovanju skupkov v VIAF pri dveh parih zapisov nastala zaradi napačne povezave avtorjev $v$ bibliografskih zapisih $v$ bazi podatkov COBIB.SI. Pri vseh primerih napačnih povezav v VIAF gre za soimenjake, pri katerih so v bibliografskih zapisih v poljih 70X-Osebno ime vpisani CONOR.SI-ID-ji soimenjakov, in ne pravih avtorjev. Posledica tega je, da so $v$ VIAF vsi soimenjaki združeni $v$ isti skupek. $V$ bazi podatkov CONOR.SI je pet soimenjakov z imenom Franc Žižek, od katerih so tri normativne točke dostopa napačno vpisane $v$ bibliografskih zapisih. $V$ štirih bibliografskih zapisih je bil napačno vpisan normativni zapis za Žižek, Franc (CONOR.SI-ID 5182819) namesto normativnega zapisa za Žižek, Franc, 1876-1938 (CONOR.SI-ID 5182563) in v dveh namesto normativnega zapisa za Žižek, Franc, 1944- (CONOR.SI-ID 2249571). Prvi avtor deluje na področju agronomije, drugi je bil pravnik, tretji pa je deloval na področju tekstilne industrije. V VIAF sta samo dva zapisa: Žižek, Franc (CONOR.SI-ID 5182819) in Žižek, Franc, 1876-1938 (CONOR.SI-ID 5182563), ki sta bila napačno združena v isti skupek (slika 4). 


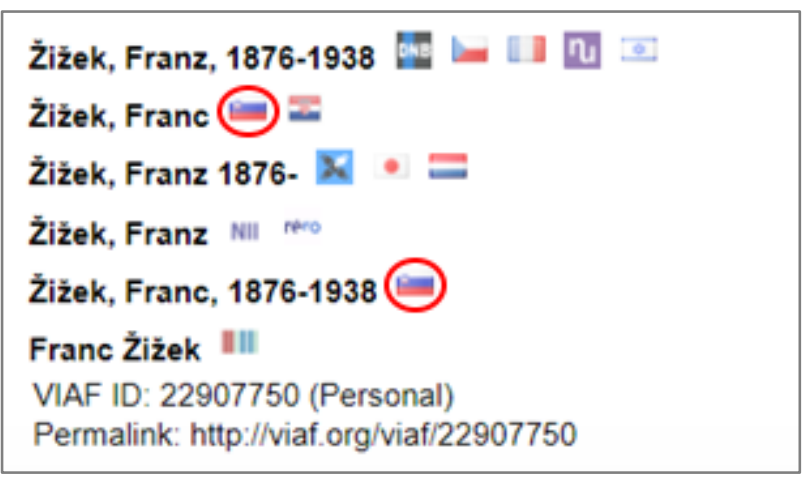

Slika 4: Skupek za normativno točko dostopa Žižek, Franc z dvema normativnima zapisoma iz baze podatkov CONOR.SI (Vir: VIAF, 2019)

Pri pregledu bibliografskih zapisov v VIAF smo ugotovili, da so vpisana dela treh različnih avtorjev - soimenjakov, kar je nastalo na osnovi napačnih povezav $v$ bibliografskih zapisih $v$ bazi podatkov COBIB.SI. Na sliki 5 (zavihek Works) so prikazani v VIAF pomešani bibliografski zapisi vseh treh avtorjev, kjer je videti, kot da gre za eno osebo, ki je delovala na več različnih področjih. $\vee$ resnici gre za tri različne avtorje, ki so delovali na različnih področjih in $v$ različnih časovnih obdobjih. Na slikah od 6 do 8 so prikazani seznami bibliografskih zapisov, povezanih $\mathrm{s}$ posameznimi avtorji, $v$ bazi podatkov COBIB.SI po popravkih.

\begin{tabular}{|c|c|c|}
\hline \multicolumn{3}{|l|}{$\square$ Works } \\
\hline Show 25 , entries & & Search: \\
\hline nele & ↔ & Sourees \\
\hline Gundriss der statistik & & 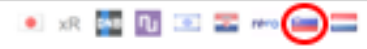 \\
\hline Stanstischen metetwerte eine methodologische untersuchung & & $x \cdot m=$ \\
\hline [Svetovni dan moknisc] [pohod ob moknscin Mure, 6. 2. 2018] & & $\odot$ \\
\hline Beitrage zur deutschen Statistik : Festgabe fur Franz Żizek zur 60 . Wederkehr seines Geburtstages & & $\Delta=$ \\
\hline Eine neve Krisenthecrie aut stanistischer Grundiage, XII. & & ㅍ \\
\hline Funt Hauptprobleme der statistischen Meehodeniehre. . & & $=\bigcirc$ \\
\hline Nichoborrekte stabstische Vertanren & & $+\infty$ \\
\hline Oyo tokeigaku & & - \\
\hline Soziologe und Statistik. & & $\nabla \Perp m \odot=$ \\
\hline Tekstini priročnik & & $\odot$ \\
\hline Textile industry handbook. & & $\odot$ \\
\hline Toketieki chosochi ron & & - \\
\hline Urejanje kmetiskega prostora na comokju obtine Ljutomer. Diploma & & $\odot$ \\
\hline We statistische Zamien entstehen : die entscheidenden methodischen Vorgange & & $\Delta=\square$ \\
\hline 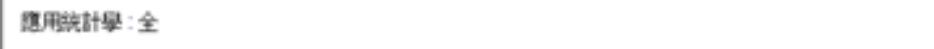 & & na $\bullet$ \\
\hline 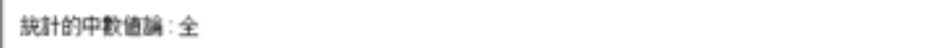 & & $\mathrm{se} \cdot$ \\
\hline
\end{tabular}

Slika 5: Združena dela dveh avtorjev zaradi vpisa napačnih normativnih točk dostopa v bibliografskih zapisih v bazi podatkov COBIB.SI (Vir: VIAF, 2019) 


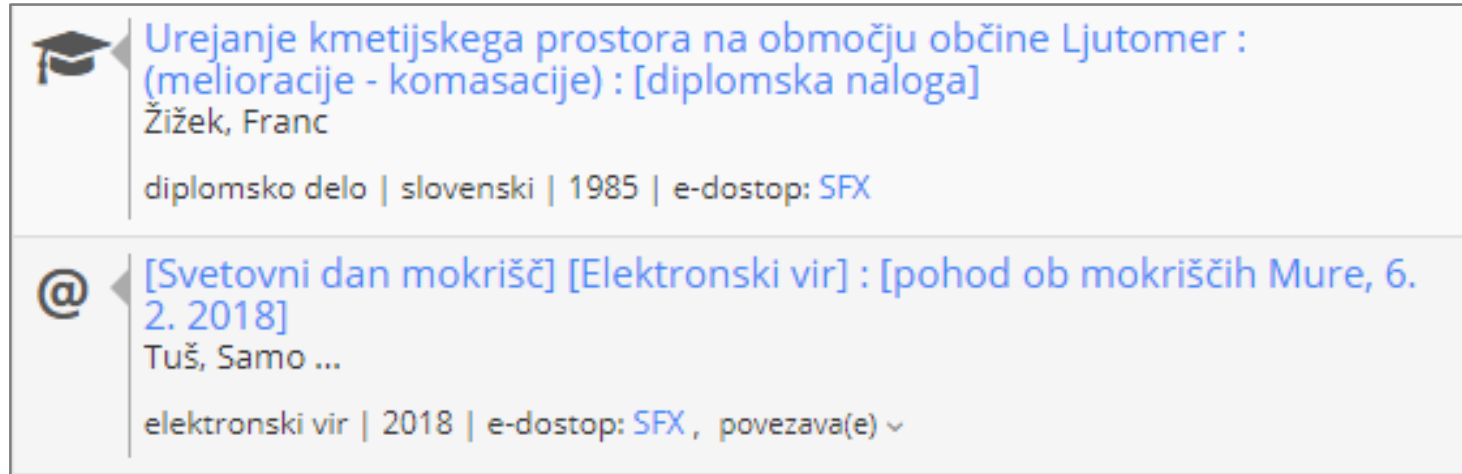

Slika 6: Deli, povezani z normativno točko dostopa Žižek, Franc (Vir: COBIB.SI, 2019)

\begin{tabular}{|l|l|}
\hline 目 & $\begin{array}{l}\text { Tekstilni priročnik } \\
\text { Kočevar, Franjo ... } \\
\text { priročnik | slovenski | } 1986 \text { | e-dostop: SFX }\end{array}$ \\
目 $\begin{array}{l}\text { Tekstilni priručnik } \\
\text { Kočevar, Franjo ... } \\
\text { priročnik | hrvaški, srbski | 1987 | e-dostop: SFX }\end{array}$ \\
\hline
\end{tabular}

Slika 7: Deli, povezani z normativno točko dostopa Žižek, Franc, 1944- (Vir: COBIB.SI, 2019)

\begin{tabular}{|l|l|}
\hline & $\begin{array}{l}\text { Meinen Kritikern : Erläuterungen und Ergänzungen zu "Grundriß der } \\
\text { Statistik" und zu "Fünf Hauptprobleme der statistischen } \\
\text { Methodenlehre" } \\
\text { Žižek, Franc, 1876-1938 } \\
\text { separat | nemški | } 1924 \text { | e-dostop: SFX }\end{array}$ \\
\hline $\begin{array}{l}\text { Grundriss der Statistik } \\
\text { Žižek, Franc, 1876-1938 } \\
\text { knjiga | nemški | 1923 | e-dostop: SFX }\end{array}$ \\
$\begin{array}{l}\text { Fünf Hauptprobleme der statistischen Methodenlehre } \\
\text { Žižek, Franc, 1876-1938 } \\
\text { knjiga | nemški | 1922 | e-dostop: SFX }\end{array}$ \\
$\begin{array}{l}\text { Soziologie und Statistik } \\
\text { Žižek, Franc, 1876-1938 } \\
\text { knjiga | nemški | 1912 | e-dostop: SFX }\end{array}$ \\
\hline
\end{tabular}

Slika 8: Dela, povezana z normativno točko dostopa Žižek, Franc, 1876-1938 (Vir: COBIB.SI, 2019)

\subsection{Razlike v katalogizacijskih pravilih}

Zaradi različnih katalogizacijskih pravil sodelujočih ustanov sta se pri enem paru normativnih zapisov združila dva normativna zapisa za osebno ime avtorja, ki je spremenil ime. Ne gre za psevdonim, ampak za spremembo osebnega imena $v$ hebrejsko obliko. $V$ bazi podatkov 
CONOR.SI je za prvotno osebno ime Fischl, Viktor, 1912-2006 (CONOR.SI-ID 24032099) kreiran en normativni zapis, za ime v hebrejščini Dagan, Avigdor, 1912-2006 (CONOR.SI-ID 84234339) pa drug normativni zapis. "Če tuji avtor uporablja za različna področja ustvarjanja različne psevdonime oz. pravo ime in enega ali več psevdonimov, upoštevamo ustrezno normativno zbirko ali nacionalno bibliografijo, kar pomeni, da lahko izdelamo več enotnih značnic." (ZNAČKA, 2001, str. 13), to je normativnih točk dostopa. V takih primerih kreiramo dva ločena normativna zapisa, ki sta med sabo povezana prek polja 500-Sorodna točka dostopa-osebno ime. V VIAF sta v isti (mešani) skupek združena oba naša zapisa za obe imeni - Viktor Fischl in Avigdor Dagan (http://viaf.org/viaf/83981379) (slika 9).

Obstaja pa tudi samostojni skupek samo za prvotno obliko imena Viktor Fischl (http://viaf.org/viaf/93611328) (slika 10).

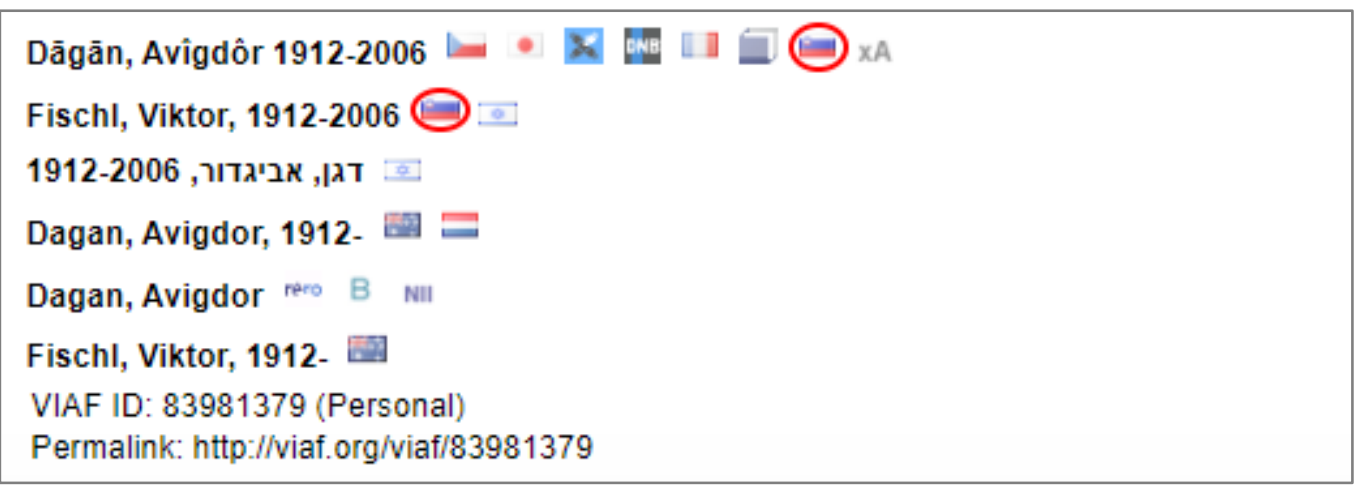

Slika 9: Mešani skupek za Viktor Fischl, 1912-2006 in Avigdor Dagan, 1912-2006 (Vir: VIAF, 2020)

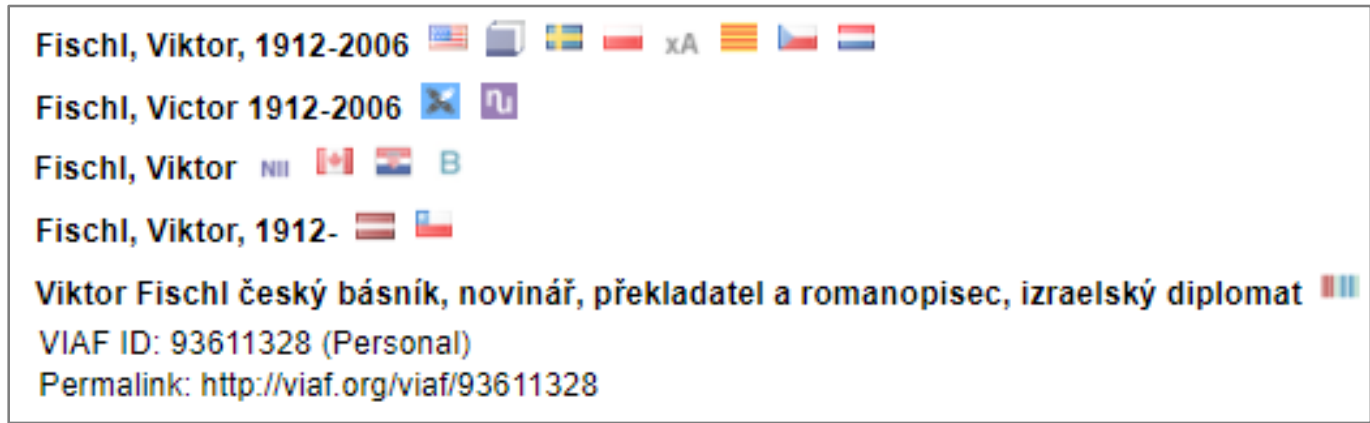

Slika 10: Skupek za normativno točko dostopa Fischl, Viktor, 1912-2006 (Vir: VIAF, 2020)

Iz VIAF smo dobili pojasnilo, da se je mešani skupek za ta primer oblikoval zaradi različnih interpretacij oblik osebnega imena. Nekatere članice VIAF obravnavajo eno izmed imen kot variantno obliko, kjer je osebno ime Fischl, Viktor, 1912-2006, ali osebno ime Dagan, Avigdor, 1912-2006, vpisano v polje 400 - Variantna točka dostopa - osebno ime, druge članice VIAF, med njimi tudi slovenske knjižnice, ki dopolnjujejo bazo podatkov CONOR.SI, pa obravnavajo obe obliki osebnega imena kot sorodni točki dostopa in ju vpišejo v polje 500 - Sorodna točka dostopa - osebno ime. Zaradi različne interpretacije sta se oba slovenska normativna zapisa znašla v istem (mešanem) skupku. Take primere v VIAF ročno ločujejo glede na vsebino polja 200 - Normativna točke dostopa - osebno ime, vendar pa ne oblikujejo treh skupkov, enega za eno obliko, drugega za drugo obliko in tretjega mešanega. Dogovorili smo se, da bodo v 
VIAF ročno prenesli normativni zapis za Fischl, Viktor, 1912-2006, na skupek za Fischl, Viktor (http://viaf.org/viaf/93611328), a ob objavi prispevka ta popravek še ni viden v VIAF.

\subsection{Napačno združevanje v VIAF}

Pri združevanju v skupke so se napačno združili 4 pari normativnih zapisov. Pri vseh primerih je napaka nastala pri soimenjakih oziroma pri avtorjih z zelo podobnimi osebnimi imeni. Zapis za osebno ime Dekleva, Jože, 1944- (CONOR.SI-ID 1849187), se je napačno združil v isti skupek z zapisom za osebno ime Dekleva, Jože, 1930-2018 (CONOR.SI-ID 182115) (slika 11). Prvi avtor piše o urbanizmu, drugi pa je bil športni novinar. V VIAF so bila zaradi združitve obeh identitet združena tudi njuna dela s področij urbanizma in športa. $V$ skupku je tudi oblika imena brez letnice, ki so ga prispevale druge članice VIAF.

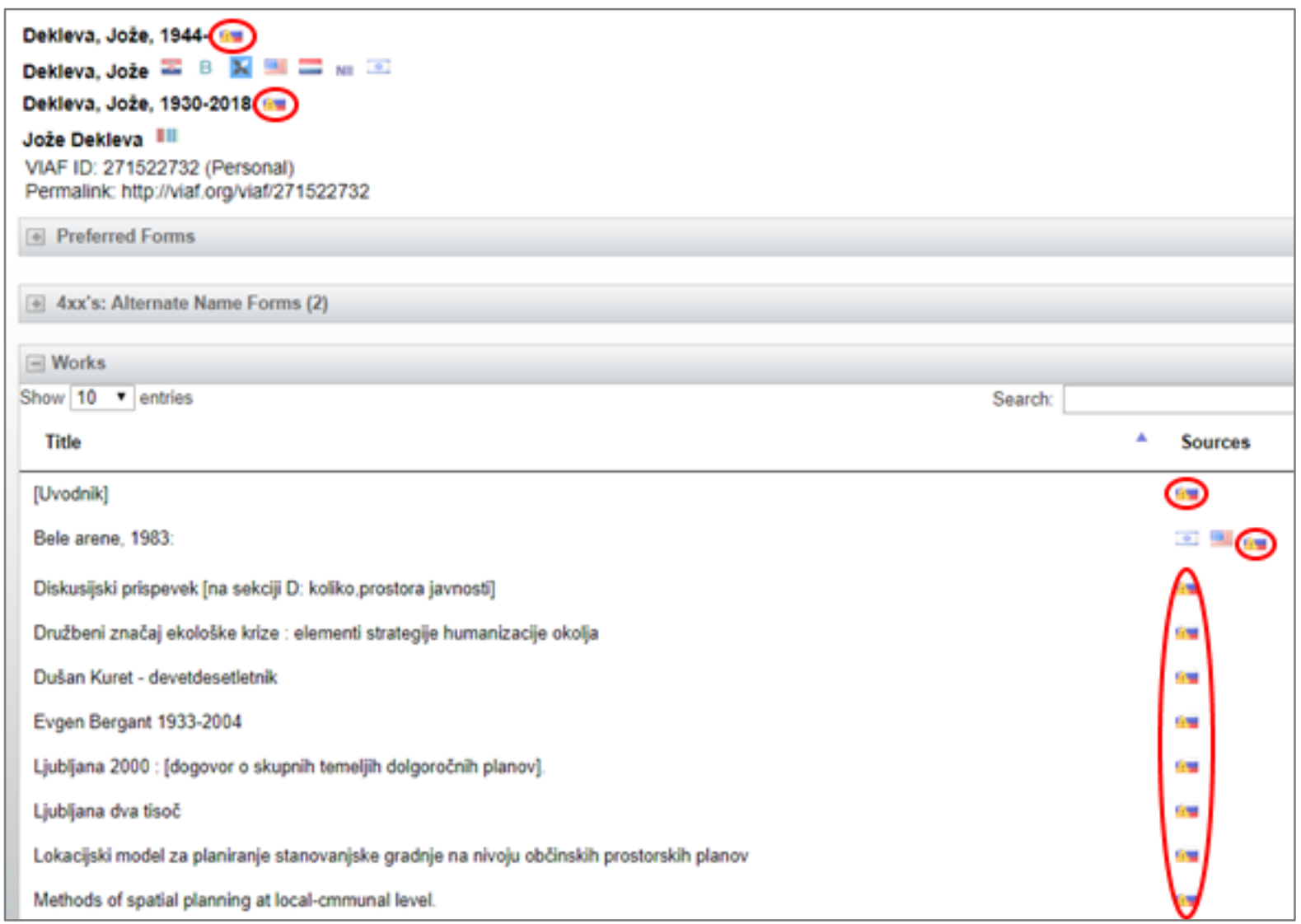

Slika 11: Napačno oblikovan skupek za normativno točko dostopa Dekleva, Jože (Vir: VIAF, 2019) 


\begin{tabular}{|ll|}
\hline ISNI: & 0000000383770109 \\
& http://isni.org/isni/0000000383770109 \\
Name: & Dekleva, Jože \\
Creation class: & Language material \\
& Text \\
Creation role: & author \\
& editor \\
Related names: & Simmie, James \\
& Simmie, James (1941-) \\
& Simmie, James Martin (1941-) \\
& Štravs, Luka \\
& Bele arene, 1983: \\
& Urejanje prostora 2 : pregled novejših raziskav \\
& Urejanje prostora na občinski ravni \\
& Yugoslavia in turmoil : after self-management? \\
& \\
& VIAF LC NSK \\
Notes: & BOWKER \\
Sources: & NTA \\
& \\
\end{tabular}

Slika 12: Napačno oblikovan zapis za identiteto Jože Dekleva (Vir: ISNI, 2020)

$\mathrm{Na}$ osnovi napačne združitve $v$ VIAF je dvema identitetama napačno dodeljen en ISNI 0000 000383770109 v bazi podatkov ISNI. V bazo podatkov ISNI, ki je osnovana na normativnih podatkih iz VIAF, se je prenesla napaka iz VIAF in se dodala še nova, saj v zapis ni prenesena letnica rojstva. Tudi $v$ ISNI sta se združili obe identiteti, tako da so dela obeh avtorjev pomešana (slika 12).

Na naš predlog so v VIAF napako odpravili. Nepravilno oblikovani skupek so razdružili in oblikovali dva ločena skupka (http://viaf.org/viaf/271522732, http://viaf.org/viaf/43236294) (slika 13). Spremembi v VIAF pa ni sledila sprememba $v$ ISNI, kjer se zapis do objave tega prispevka še ni spremenil.

\begin{tabular}{|c|c|c|c|}
\hline & Heading & Type & Sample Title \\
\hline 1 & 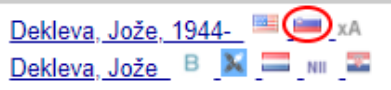 & Personal & $\begin{array}{l}\text { Diskusijski prispevek [na sekciji B: urejanje prostora med naročnikom in izvajal .... } \\
\text { Yugoslavia in turmoil : after self-management? }\end{array}$ \\
\hline 2 & 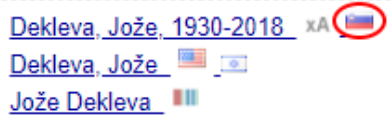 & Personal & $\begin{array}{l}\text { Bele arene, 1983: } \\
\text { Bele arene, 1983: }\end{array}$ \\
\hline
\end{tabular}

Slika 13: Razdružena skupka za soimenjaka z imenom Jože Dekleva (Vir: VIAF, 2020)

\section{Podvojeni ISNI}

$\checkmark$ bazo podatkov ISNI prispeva podatke več kot 50 ustanov z različnih področij (VIAF, nacionalne knjižnice, repozitoriji, ustanove, ki popisujejo vire s področja glasbe, in ustanove za upravljanje $z$ avtorskimi pravicami); ti podatki se povezujejo $z$ uporabo različnih algoritmov za ujemanje zapisov (How ISNI works, 2020). Težave pri povezovanju zapisov v bazi podatkov ISNI smo zasledili pri analizi vpisanih zapisov, ko smo ugotovili, da sta 107 normativnim zapisom dodeljena dva identifikatorja ISNI, nekaterim pa celo trije. Delež zapisov, pri katerih so se pojavile težave, je sicer samo 0,36 \% vseh ISNI, ki smo jih pridobili s pošiljanjem zapisov $\checkmark \mathrm{VIAF}$, a je precej velik za dodatno ročno preverjanje in usklajevanje podatkov $v$ CONOR, VIAF 
in ISNI. Seznam podvojenih identifikatorjev ISNI, za katere smo menili, da so verjetno napačno dodeljeni, smo poslali v VIAF $v$ dodatno preverjanje in usklajevanje $z$ bazo podatkov ISNI.

Ob uvedbi novega polja 010 - Mednarodni standardni identifikator imen (ISNI) v format COMARC/A smo se odločili, da bo polje neponovljivo. Takrat še nismo imeli vpogleda, koliko različnih identifikatorjev ISNI bo $v$ resnici dodeljeno isti entiteti. Odločili smo se, da bomo pri več dodeljenih ISNI za isto entiteto ročno preverjali, kateri identifikator bomo vpisali $v$ normativni zapis $v$ bazo podatkov CONOR.SI. ISNI se mora nanašati na normativno točko dostopa, ki je navedena v polju 200-Normativna točka dostopa - osebno ime. Pri podrobnejšem preverjanju zapisov $v$ bazi podatkov ISNI smo ugotovili, da se večina nanaša na isto identiteto. Večina takih primerov se nanaša na tuje avtorje, nekateri primeri pa na slovenske. Med njimi je tudi dr. Petra Černe Oven, oblikovalka in predavateljica na Akademiji za likovno umetnost in oblikovanje, ki so ji dodeljeni kar trije različni identifikatorji: ISNI 0000 00038500 0589, ISNI 000000038726 940X in ISNI 0000000112667054 (slika 14).

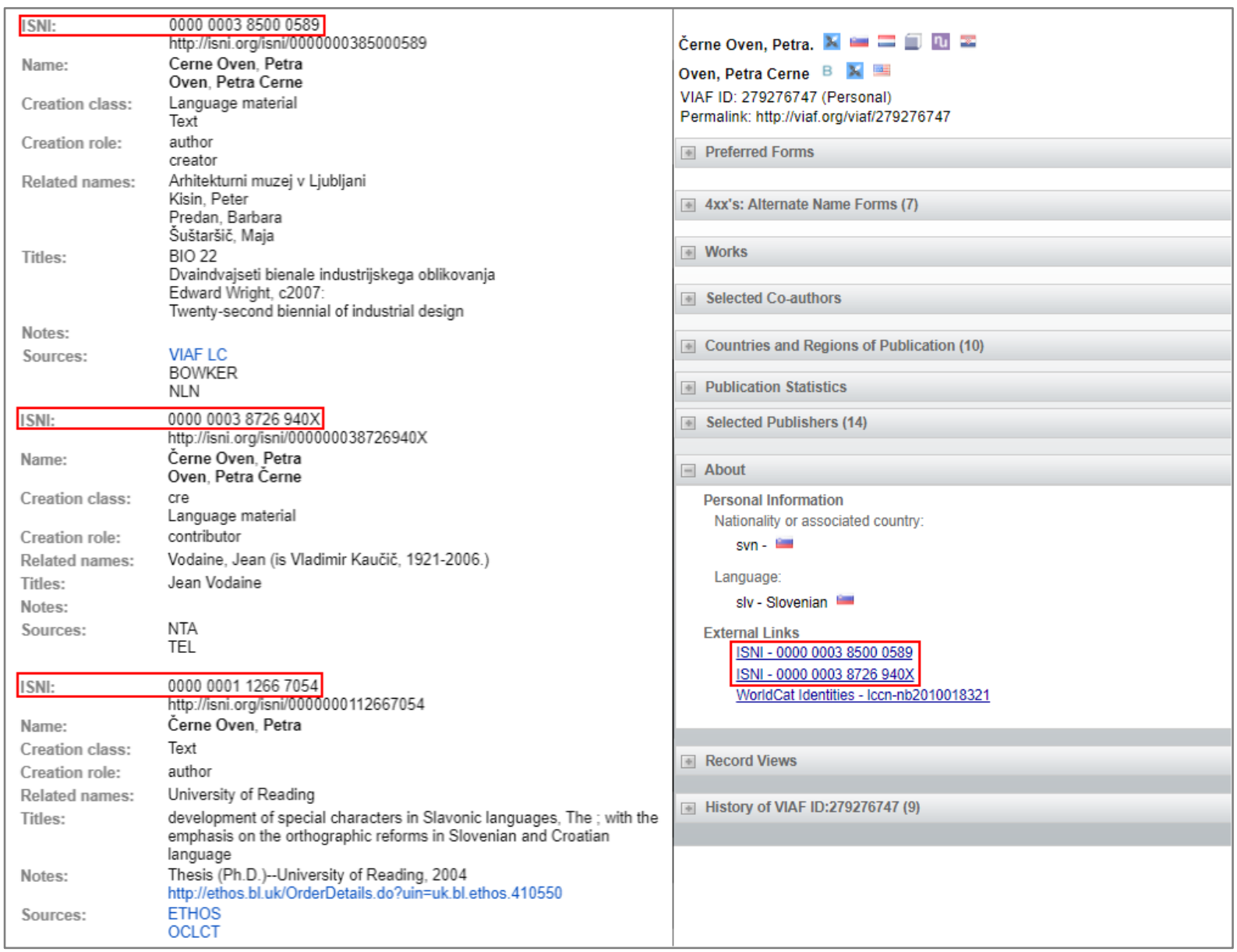

Slika 14: Trije zapisi za Petro Černe Oven v ISNI (Vir: ISNI, 2020) (levo) in skupek za normativno točko dostopa Černe Oven, Petra z dvema identifikatorjema ISNI (Vir: VIAF, 2020) (desno)

V datoteki VIAF Dataset sta dva identifikatorja (ISNI 000000038726 940X in ISNI 00000003 8500 0589), ki sta v VIAF vpisana v isti skupek (slika 14) (http://viaf.org/viaf/279276747). Prvi ISNI za osebno ime brez šumnikov (Cerne Oven, Petra) izvira iz VIAF, drugi ISNI za osebno ime s šumniki pa iz nizozemske nacionalne knjižnice (koda NTA). 
Tretji ISNI (0000 00011266 7054) je dodeljen za osebno ime s šumniki, ki izvira iz britanskega nacionalnega repozitorija doktorskih disertacij EThOS (slika 15).

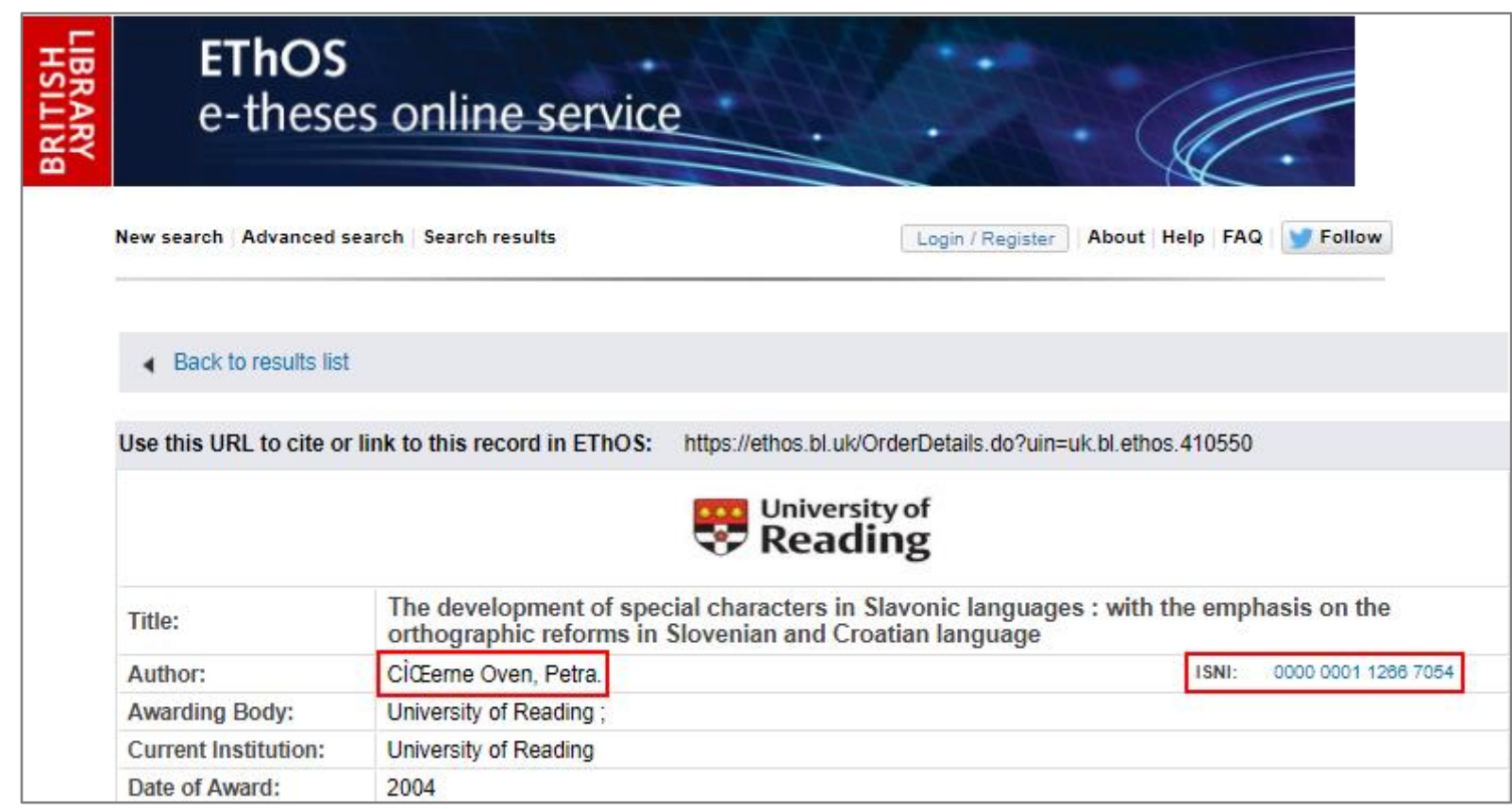

Slika 15: Zapis za Petro Černe Oven (Vir: EThOS, 2020)

Po standardu ISO 27729 se identifikator ISNI dodeli samo za eno javno identiteto osebe ali organizacije. Če ima ena oseba ali organizacija (entiteta) več kot eno identiteto, je vsaka identificirana s svojim ISNI. Alternativno črkovanje, alternativne predstavitve, različni nabori znakov, pisave ali jeziki sami po sebi ne upravičujejo dodelitve različnih identifikatorjev ISNI (ISO 27729, 2013). Opisani primer za Petro Černe Oven, ko so bili njeni identiteti dodeljeni kar trije različni ISNI, kaže, da vsak zapis izvira iz druge baze podatkov. Algoritem za povezovanje ni povezal istih oblik osebnega imena iz dveh različnih baz podatkov (nizozemske nacionalne knjižnice in EThOS), in tudi ne oblik s šumniki in brez šumnikov iz treh različnih baz podatkov. Vzpostavitev enoličnega identifikatorja za isto identiteto ni uspela pri enostavnih različicah osebnega imena s šumniki in brez njih, zahtevnejših primerov, kot so druge pisave in različna transliteracija (npr. cirilica) normativnih oblik z dodatki $k$ imenu v jeziku ustanove, pa nismo preverjali oz. takšnih primerov nismo zasledili.

\section{Priporočila za kakovostnejši prikaz slovenskih normativnih zapisov v VIAF}

$\mathrm{Na}$ podlagi analize vpisa in ažuriranja $\mathrm{v}$ VIAF smo katalogizatorjem pripravili osnovna priporočila za oblikovanje normativnih zapisov za osebna imena v bazi podatkov CONOR.SI, ki bodo prispevala $\mathrm{k}$ izboljšanju prikaza slovenskih normativnih zapisov v VIAF. Pri določanju normativne točke dostopa je treba upoštevati katalogizacijska pravila in navodila (gl. ZNAČKA), pri oblikovanju drugih delov normativnega zapisa pa navodila $v$ priročniku o formatu COMARC/A.

\subsection{Priporočila za oblikovanje normativnih zapisov za osebna imena}

Dokončno urejeni zapis. Zapis je dokončno urejen, kadar znamo določiti enotno točko dostopa in smo zbrali dovolj podatkov o osebnem imenu. Ko zapis dokončno uredimo, $v$ 
podpolje 001a - Status zapisa vpišemo kodo "c" - popravljen zapis in brišemo kodo "3" nepopoln zapis v podpolju 001g - Koda popolnosti zapisa (Kos, 2019).

Pomembnost kodiranih podatkov. Pri dokončno urejenem normativnem zapisu navedemo vse ustrezne kode, zlasti pa tiste, na katerih temelji izbor zapisov za VIAF. To so:

- $001 a=» c \ll-$ popravljen zapis,

- $001 c=» a \ll-o s e b n o$ ime,

- $100 b=» a \ll-s p r e j e t a$,

- $120 b=» a \lll-r a z l i k o v a n o$ osebno ime.

Če je le mogoče, kodiranih podatkov, na katerih temelji izbor zapisov za VIAF, ne spreminjamo več.

Različne oblike imena. V normativnem zapisu navedemo vse variantne oblike osebnega imena (polje 400-Variantna točka dostopa-osebno ime) iz različnih virov, ki imajo zapise v COBIB.SI.

Obogateni zapisi. Zapise obogatimo tudi z javno dosegljivimi podatki o biografiji in delovanju osebe (polje 340 - Opomba o biografiji in delovanju), ki jih lahko preverimo v slovenskih virih ali pri avtorju. Zapise lahko obogatimo tudi z dodatnimi informacijami v drugih poljih, v polju 856 - Elektronska lokacija in dostop recimo lahko navedemo slovenske spletne biografske leksikone, npr. Štajerci.si (www.stajerci.si), kot to že delajo v Mariborski knjižnici (slika 16).

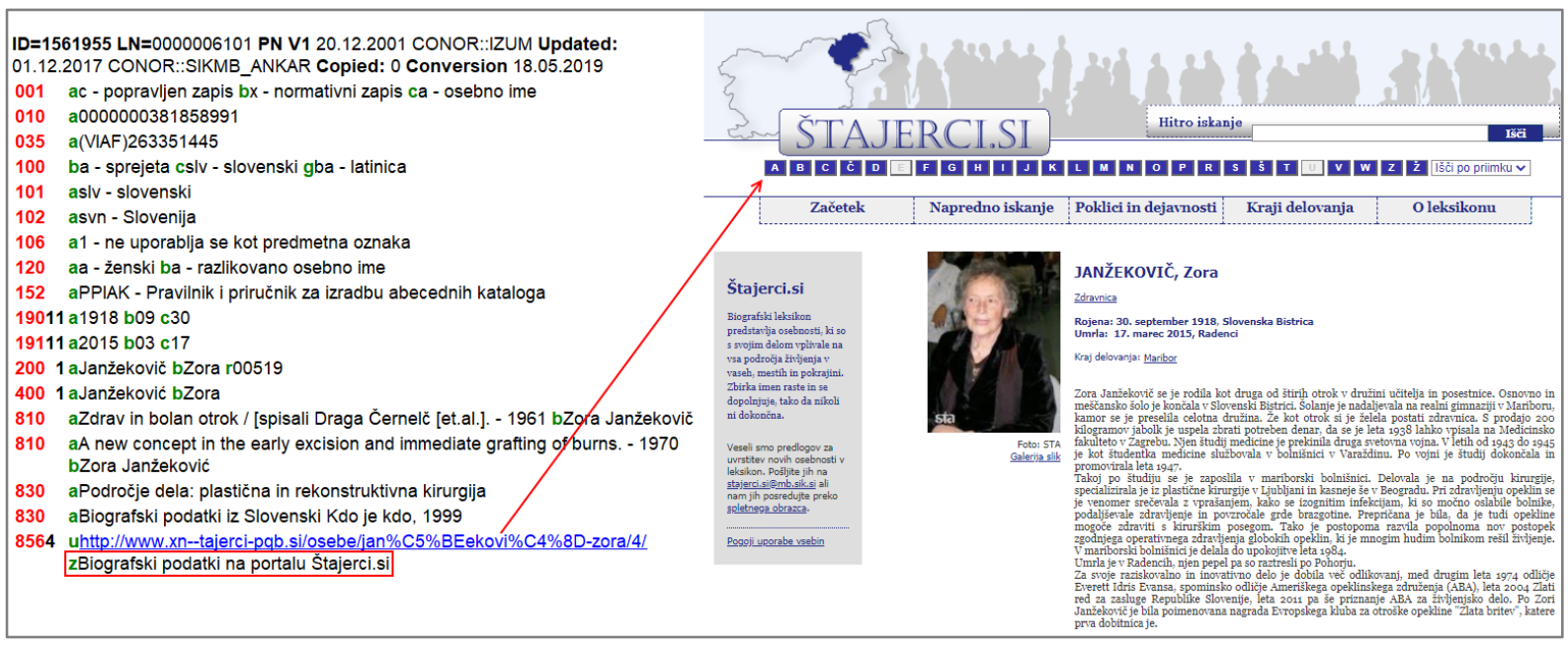

Slika 16: Biografski podatki za Zoro Janžekovič (Vir: Štajerci.si, 2020) (levo) in normativni zapis za Zoro Janžekovič (Vir: CONOR.SI, 2020) (desno)

Soimenjaki. Pri osebnih imenih nastane največ napak pri soimenjakih, zato je treba že pri kreiranju in urejanju normativnih zapisov posebno pozornost posvetiti soimenjakom. Poleg pazljivega oblikovanja normativne točke dostopa je treba zapise opremiti s pojasnilom o entitetah $z$ enakimi ali podobnimi imeni. To naredimo z vpisom opombe $» N e$ zamenjuj:« v polju 820 - Podatki o rabi ali pomenskem obsegu. Razen tega je treba pri povezovanju $v$ bibliografskih zapisih v poljih $70 X$ skrbno preveriti pravilnost povezave do normativnega zapisa za osebno ime avtorja (slika 17). 


\begin{tabular}{|c|c|}
\hline \multicolumn{2}{|l|}{$\forall$ Povezovanje z zapisi iz CONOR.SI } \\
\hline \multirow{7}{*}{$\begin{array}{l}\text { Žižek, Franc } \\
\text { Žižek, Franc, 1876-1938 } \\
\text { Žižek, Franc, 1944- <04432> } \\
\text { Žižek, Franc, 1955- <09739> } \\
\text { Žižek, Franc, zdravnik } \\
\text { Žižek, Franci } \\
\text { Žižek, Franc, 1944- <04432> } \\
\text { Žižek, Franci, 1983- } \\
\text { Žižek, Francka <nepopolna identifikacija> } \\
\text { Žižek, Franček <nepopolna identifikacija> }\end{array}$} & LC/NAF \\
\hline & Prikaži \\
\hline & Seznam \\
\hline & Dodaj v odložišče \\
\hline & Nov zapis \\
\hline & Naslednji zapis \\
\hline & 슬 Prejšnji zapis \\
\hline žižek, franc & Poveži Prekliči \\
\hline
\end{tabular}

Slika 17: Izpis seznama soimenjakov pri vnosu imena avtorja v bibliografski zapis (Vir: COBIB.SI, 2020)

Podvojeni zapisi. Da bi se izognili kreiranju več zapisov za isto osebo, tj. podvojenim zapisom, je treba pred kreiranjem normativnega zapisa iskati po več različnih kriterijih, preveriti točke dostopa $v$ drugih zapisih in dosledno preverjati priporočene popravke ob shranjevanju zapisa. Uporabimo tehnike iskanja, s katerimi lahko preprečimo nastanek podvojenih normativnih zapisov (Kos, 2018).

Povezovanje normativnih zapisov z bibliografskimi zapisi. Tiste bibliografske zapise, pri katerih manjka podatek v podpolju 70X3 - Številka normativnega zapisa, je treba povezati z normativnimi zapisi za osebna imena. $V$ bazi podatkov COBIB.SI je bilo konec leta 2019 še okrog $23 \%$ bibliografskih zapisov, v katerih polja 70X niso povezana z normativnimi zapisi za osebna imena (IZUM, 2020). Priporočamo povezovanje bibliografskih zapisov z normativnimi predvsem za slovenske avtorje (metoda Poveži z značnicami v bibliografskih zapisih, ki je opisana v priročniku COBISS3/Katalogizacija, pogl. 9.4.3).

\subsection{Priporočila za ravnanje z normativnimi zapisi, ki so že bili poslani v VIAF}

V normativnih zapisih $v$ bazi podatkov CONOR.SI, ki so že bili poslani v VIAF, ne spreminjamo kodiranih podatkov, na katerih je temeljil izbor zapisov za VIAF, in ne popravljamo in ne brišemo identifikatorja VIAF ID, ker se vpisuje programsko in je osnova za povezavo iz COBISS+ do skupka v VIAF. Identifikator ISNI lahko spremenimo, če ugotovimo, da pripada drugi bibliografski identiteti. Eni osebi je lahko dodeljen več kot en ISNI, in sicer za vsako javno identiteto svoj (recimo psevdonim Prežihov Voranc in pravo ime Lovro Kuhar imata vsak svoj ISNI). Pri preverjanju pravilnosti ISNI pa moramo upoštevati, da se $v$ bazi podatkov CONOR.SI identifikator ISNI nanaša na identiteto, povezano z osebnim imenom, ki je vpisano v polju 200 - Normativna točka dostopa-osebno ime.

\section{Razprava}

Vpis normativnih zapisov $v$ VIAF pomeni vključitev slovenskih normativnih podatkov $v$ mednarodni okvir, glavna prednost pa je pridobitev identifikatorja ISNI. Z vpisom smo za $50,3 \%$ poslanih zapisov brezplačno pridobili identifikator ISNI, ki je sicer plačljiv. Poleg ISNI smo $v$ normativne zapise $v$ bazi podatkov CONOR.SI programsko vpisali tudi VIAF ID. Na tej 
osnovi smo lahko v COBISS+ vzpostavili povezave do servisov VIAF in ISNI v zapisih, ki so vpisani v VIAF.

Pri prvem ažuriranju, novembra 2019, so bili v VIAF vpisani tudi normativni zapisi za imena korporacij. Teh zapisov je bilo zelo malo, le 74 ali komaj 0,5 \% vseh zapisov za imena korporacij $\checkmark$ bazi podatkov CONOR.SI, čeprav smo normativno kontrolo korporacij vzpostavili leto prej, jeseni 2018. Delež zapisov za osebna imena, ki smo jih prispevali v VIAF, je sicer desetkrat večji, a še zmeraj znaša le $5 \%$ vseh zapisov za osebna imena v bazi podatkov CONOR.SI. Glede na to, da je normativna kontrola za osebna imena v sistemu COBISS.SI vzpostavljena že 17 let, je tudi ta delež bistveno premajhen. Glavni razlog je treba iskati pri katalogizatorjih, ki posvečajo premalo pozornosti preverjanju in urejanju normativnih podatkov. Večina jih kreira zapise z nesprejeto obliko osebnega imena ali kratke normativne zapise. Skrajni čas je, da katalogizatorji spremenijo svoje razmišljanje pri kreiranju in redigiranju normativnih zapisov, ki velja za najzahtevnejše delo v postopkih katalogizacije. Da lahko normativna točka dostopa pridobi status sprejeta, je treba preveriti identiteto avtorja, da pa lahko zapis dobi status popravljen zapis, pa je treba urediti normativni zapis, da je dokončno popravljen, tj. brez slovničnih in vsebinskih napak (Krajnc Vobovnik, 2018). Prednostna naloga katalogizatorjev bi morala biti, da predvsem za slovenske avtorje normativne zapise dokončno uredimo in opremimo z biografskimi podatki in s povezavami na spletne biografske vire.

Glede na vrste problemov, navedenih v VIAF Guidelines (2019), smo pri vpisu v VIAF zasledili le napačne povezave med normativnimi in bibliografskimi zapisi ter podvojene normativne zapise (tabela 1). Vsi problemi pri združevanju v skupke v VIAF, ki smo jih zasledili pri analizi napačno povezanih normativnih zapisov iz baze podatkov CONOR.SI, izhajajo iz napake, ko se pri katalogizaciji nepravilno identificirajo soimenjaki.

Tabela 1: Vrste napak pri vpisu slovenskih normativnih zapisov v VIAF glede na tipologijo problemov pri združevanju v skupke $v$ VIAF

\begin{tabular}{l|l}
\hline Problemi po VIAF Guidelines (2019) & $\begin{array}{l}\text { Problemi pri vpisu zapisov CONOR.SI v VIAF } \\
\mathbf{( 2 0 1 9 )}\end{array}$ \\
\hline mešana imena (mešani homonimi) & $/$ \\
\hline manjkajoči naslovi del in datumi & $\begin{array}{l}\text { napačne povezave z normativnimi zapisi v } \\
\text { bibliografskih zapisih v bazi podatkov COBIB.SI }\end{array}$ \\
\hline neobičajno kodirani podatki & $/$ \\
\hline $\begin{array}{l}\text { razlikovanje z uporabo jezikovno odvisnih } \\
\text { podatkov }\end{array}$ & $/$ \\
\hline podvojeni zapisi & podvojeni zapisi \\
\hline klasična imena, imena kraljev, kraljic in papežev & $/$ \\
\hline
\end{tabular}

Tudi če odpravimo vse napake, ki izvirajo iz izvornih podatkov $v$ sistemu COBISS.SI, se napačnemu združevanju v VIAF ne moremo v celoti izogniti. VIAF namreč združuje zapise, kreirane po različnih katalogizacijskih pravilih, in eden izmed ciljev je tudi ohranitev nacionalnih in lokalnih oblik imena v normativnih zapisih. Zato lahko pričakujemo, da se bodo napake pojavljale še naprej. Pomembno pa je, da se zavedamo, katerim napakam se pri katalogizaciji lahko izognemo in katerim težje. 
Več dodeljenih ISNI za isto identiteto, ki smo jih odkrili pri preverjanju VIAF Dataset, pomeni, da se izgubita pomen in namen enoličnega identifikatorja za javno identiteto neke osebe. Gre za nekonsistentnost baze podatkov ISNI, zato bomo pri razreševanju še naprej sodelovali $S$ sodelavci VIAF, da uredijo podvojene identifikatorje predvsem za slovenske avtorje $v$ VIAF in v ISNI.

Pri vodenju projekta vpisa normativnih zapisov $v$ VIAF smo glede na analizo vhodnih in izhodnih podatkov pripravili še nekaj dodatnih priporočil za katalogizacijo normativnih zapisov. Priporočila se nanašajo predvsem na osebna imena in so katalogizatorjem splošno znana. $V$ prispevku izpostavljamo, kaj najbolj vpliva na uspešnost združevanja v skupke v VIAF. Poleg tega želimo spodbuditi katalogizatorje, da predvsem za slovenske avtorje kreirajo dokončno urejene normativne zapise tako za osebna imena kot za imena korporacij, saj so samo dokončno urejeni normativni zapisi (s statusom popravljen zapis) primerni za izmenjavo na mednarodnem nivoju.

\section{Zaključek}

Še naprej bomo pošiljali normativne zapise za osebna imena in imena korporacij v VIAF. Trenutno je v VIAF vpisanih samo 5,05 \% vseh normativnih zapisov v bazi podatkov CONOR.SI, $s$ katerimi smo zajeli 38,5 \% bibliografskih zapisov v bazi podatkov COBIB.SI. Glede na inicialni vpis je to le malenkostno povečanje, naš cilj pa je, da vsako leto v VIAF pošljemo čim več čim boljših normativnih zapisov, in to ne samo za osebna imena, ampak tudi za imena korporacij. $S$ priporočili za oblikovanje normativnih zapisov v CONOR.SI ozaveščamo katalogizatorje o pomenu normativne kontrole na globalnem nivoju, o vplivu nesporno in nedvoumno oblikovane normativne točke dostopa ter o pomenu vpisanih osnovnih podatkov o delovanju osebe predvsem za slovenske avtorje. Enako velja tudi za normativne zapise za imena korporacij, predvsem slovenskih, in za čim večje povezovanje le-teh z bibliografskimi zapisi.

Kakovostna, konsistentna in bogata nacionalna normativna baza podatkov, ki je $v$ največji možni meri povezana z bibliografsko bazo podatkov, je osnova za vzpostavitev modela IFLA LRM (angl. Library Reference Model) v sistemu COBISS.SI. V vmesniku COBISS+, ki smo ga objavili novembra 2016, smo oblikovali skupke zapisov z namenom, da identificiramo bibliografske odnose $v$ katalogu. Skupke smo oblikovali za dela in njihove pojavne oblike, ki smo jih pridobili na osnovi različnih algoritmov in jih prikazali kot "Vse izdaje in prevodi« (Krajnc Vobovnik in Mazić, 2017). Od začetka leta 2020 pripravljamo osnove za vzpostavitev normativnih zapisov za dela in pojavne oblike, ki jih bomo vpisali v bazo podatkov CONOR.SI ter kasneje tudi v VIAF.

\section{Reference}

Bennet, R., Hengel-Dittrich, C., O'Neill, E. T. in Tillet, B. B., 2006. VIAF (Virtual International Authority File): Linking Die Deutsche Bibliothek and Library of Congress Name Authority File. V: World Library and Information Congress: 72nd IFLA General Conference and Council, August 2006, Seoul, Korea. Dostopno na: https://archive.ifla.org/IV/ifla72/papers/123Bennett-en.pdf [18. 3. 2020].

COBISS3/Katalogizacija, 2020. Maribor, Institut informacijskih znanosti. Dostopno na: https://izobrazevanje.izum.si/EntryFormDesktopDefault.aspx?tabid=38\&type=manual\&man ual=1_COBISS3_Katalogizacija_svn [18.3. 2020]. 
How ISNI works, 2020. Dostopno na: http://www.isni.org/how-isni-works [18. 3. 2020].

ISO (International Organization for Standardization), 2013. Slovenski standard SIST ISO 27729:2013. Informatika in dokumentacija - Mednarodni standardni identifikator imen (ISNI) - Information and Documentation - International standard name identification (ISNI) Information et documentation - Code international normalisé des nomes (ISNI). Ljubljana: Slovenski inštitut za standardizacijo.

IZUM, 2020. Letno poročilo o delu IZUM za leto 2019. (Priloga 3: Statistika bibliografskih zapisov, povezanih z normativno bazo podatkov CONOR.SI.). Maribor, Institut informacijskih znanosti.

Kos, J., 2019. Kako sestavimo normativni zapis za osebno ime. Blog COBISS, 8. 10. 2019. Dostopno na: https://blog.cobiss.si/2019/10/08/sestavimo_normativni_zapis/ [18. 3. 2020]. Kos, J., 2018. Tehnike iskanja v CONOR.SI pri kreiranju normativnih zapisov za osebna imena avtorjev. Blog COBISS, 22. 6. 2018. Dostopno na: https://blog.cobiss.si/2018/06/22/tehnikeiskanja-conor/ [18. 3. 2020].

Krajnc Vobovnik, A., 2018. Vpis slovenskih normativnih zapisov za osebna imena v VIAF. Organizacija znanja (23), 1-2, str. 11-20. Dostopno na:

https://www.cobiss.si/oz/HTML/OZ_2018_1_2_final/14/index.html [18. 3. 2020].

Krajnc Vobovnik, A. in Mazić G., 2017. Združevanje bibliografskih zapisov v COBISS+. Knjižnica (61), 1/2, str. 87-100. Dostopno na: https://knjiznica.zbds-

zveza.si/knjiznica/article/view/6163 [18. 3. 2020].

VIAF Guidelines, 2019. Dostopno na:

https://www.oclc.org/content/dam/oclc/viaf/VIAF\%20Guidelines.pdf [18. 3. 2020].

ZNAČKA: priročnik za določanje značnic pri katalogizaciji, 2001. Ljubljana, Narodna in univerzitetna knjižnica. Dostopno na: http://home.izum.si/izum/e-prirocniki/znacka.pdf [18. 3. 2020]. 